\begin{tabular}{|c|c|c|}
\hline \multicolumn{3}{|c|}{$\begin{array}{l}\text { OPEN O ACCESS Freely available online } \\
\text { http://www.banglajol.info/index.php/BJID/index }\end{array}$} \\
\hline Case Report & & \\
\hline Bangladesh Jo & 1 of Infectious Diseases & \\
\hline $\begin{array}{l}\text { October 2020, Volume } 7,1 \\
\text { ISSN (Online) 2411-670X }\end{array}$ & Suppl_2, Page S57-S60 & \\
\hline ISSN (Print) 2411-4820 & DOI: https://doi.org/10.3329/bjid.v7i00.50164 & \\
\hline
\end{tabular}

\title{
A Case Report of Recurrent Covid-19 Infection of a Physician in Bangladesh: Re-infection or Persistence Infection?
}

\author{
Lubana Akram ${ }^{1}$, Md Harun Ur Rashid $\mathrm{Khan}^{2}$, Asif Iqbal ${ }^{3}$, Arifa Akram ${ }^{4}$
}

${ }^{1}$ Post Graduate [MD] Resident, Department of Paediatric Gastroenterology, Bangabandhu Sheikh Mujib Medical University, Dhaka, Bangladesh; ${ }^{2}$ Junior Consultant (Cardiology), Upazilla Health Complex, Shibchar, Madaripur, Bangladesh; ${ }^{3}$ Curator, Institute of Epidemiology, Disease Control \& Research, Dhaka, Bangladesh; ${ }^{4}$ Assistant Professor, Department of Virology, National Institute of Laboratory Medicine and Referral center, Dhaka, Bangladesh

[Received: 17 August 2020; Accepted: 28 September 2020]

\begin{abstract}
The novel coronavirus disease (COVID-19) has created a large problem to the healthcare system all over the world. "Retest Positive" for SARS-CoV-2 from "recovered" patients (COVID-19) has been reported recently which raised several questions for the COVID-19 disease. In this case report, we had described a patient who became positive after 1 month from the initial infection with SARS-CoV-2. It is therefore possible that recurrences should be actually persistent infections in which PCR resulted falsely negative during initial infection when he left home isolation assuming himself disease free. The discharge criteria should be ensured for a recovered patient to prevent the relapse or persistence of COVID-19. [Bangladesh Journal of Infectious Diseases, October 2020;7(suppl_2):S57-S60]

Keywords: COVID-19; discharge; recurrence; persistence; RT-PCR

Correspondence: Dr. Arifa Akram, Assistant Professor, Department of Virology, National Institute of Laboratory Medicine and Referral Center, Sher-E-Bangla Nagar, Dhaka, Bangladesh; Cell no.: +8801816296249; Email: drbarna43@gmail.com; ORCHID id : 0000-0001-8829-9817

Conflict of interest: The authors declare that they have no known competing financial interest or personal relationships that could have appeared to influence the work reported in this paper.

Funding agency: This research did not receive any specific grant from funding agencies in the public, commercial or not for profit sectors.

Contribution to authors: Akram L, Khan MHUR, Iqbal A, Akram A involved diagnosis, literature search up to manuscript writing and revision.

How to cite this article: Akram L, Khan MHUR, Iqbal A, Akram A. A Case Report of Recurrent Covid-19 Infection of a Physician in Bangladesh: Re-infection or Persistence Infection? Bangladesh J Infect Dis 2020;7(suppl_2):S57-S60

Copyright: @2020. Akram et al. Published by Bangladesh Journal of Infectious Diseases. This article is published under the Creative Commons CC BY-NC License (https://creativecommons.org/licenses/by-nc/4.0/). This license permits use, distribution and reproduction in any medium, provided the original work is properly cited, and is not used for commercial purposes.
\end{abstract}

\section{Introduction}

Severe Acute Respiratory Syndrome Coronavirus 2 (SARS-CoV-2) causes Coronavirus disease 2019 (COVID-19), which emerged in China and spread throughout the world. Approximately, three million individuals are diagnosed with COVID-19, whereas 0.2 million are reported deaths ${ }^{1}$. Already there are known 80 distinct genotypic variants of this virus as per another study which advances the concern for effective vaccine production and also might 
contribute to the variations of presentations in different countries ${ }^{2}$.

All patients with COVID-19 need to meet criteria of recovery before hospital discharge in Bangladesh: 1. Resolution of fever without the use of feverreducing medications e.g paracetamol for at least three days 2. Significant improvement in the respiratory symptoms (e.g., cough, shortness of breath) for consecutive three days 3. After discharge, continue home or facility isolation for the duration which extends from the day of symptom onset to 21th day for hospitalized patients 4. Two consecutively reverse transcription-polymerase chain reaction (RT-PCR) tests negative for SARS-CoV-2 RNA more than 24 hours. But the last criteria was excluded later from the updated version of guideline ${ }^{3}$. However, the recovered (discharged) COVID-19 patients with retest positive for SARS-CoV-2 RNA have recently been reported ${ }^{4-12}$.

A new report on 25 February 2020 indicated that $14 \%$ of discharged patients were tested positive for SARS-CoV-2 RNA in Guangdong province of China. On 2 February 2020, a woman patient with COVID-19 became positive for SARS-CoV-2 RNA again during her quarantine after hospital discharge because of two consecutively negative results on 28 and 30 January, respectively.

Another single center study reported that 8 out of 108 confirmed patients with COVID-19 from 10 February to 13 April 2020 became SARS-CoV-2 positive and were re-admitted in hospital. ${ }^{6}$ This "Retest Positive" for SARS-CoV-2 from the discharged COVID-19 has attracted extra attention and triggered numerous discussions ${ }^{13}$. The brief report describes that a physician of Bangladesh who became positive after 1 month from the initial infection with SARS-CoV-2.

\section{Case Presentation}

The patient is a physician of 40 years working in Upazilla Health Complex, Shibchar, Madaripur, Bangladesh from last 6 months. His parents were diagnosed as COVID 19 positive cases on $25^{\text {th }}$ April, 2020. From $1^{\text {st }}$ May, he felt low grade fever and mild cough. As his family history was positive, he tested RT PCR for SARS-CoV-2 and became positive on $3^{\text {rd }}$ May, 2020. After that he was in isolation for 15 days at home as his symptoms were mild in nature. His highest body temperature was 39 ${ }^{\circ} \mathrm{C}$, with cough and fatigue, without asthma and dyspnea. He monitored his vital signs regularly and his oxygen saturation was $98 \%$. Routine blood tests, renal function, serum electrolyte, D dimer, serum ferritin, serum procalcitonin and liver function tests were normal (Table 1) except SGPT which was mildly increased (67 U/L). His chest $\mathrm{x}$-ray was normal.

Table 1: Investigation Shown During Initial And Later Infection

\begin{tabular}{|l|c|c|}
\hline \multirow{2}{*}{ Investigations } & \multicolumn{2}{|c|}{ Findings with Reference Range } \\
\cline { 2 - 3 } & \multicolumn{1}{|c|}{ 7 May, 2020 } & 27 June, 2020 \\
\hline HB\% & $15.3 \mathrm{gm} / \mathrm{dL}$ & $15.1 \mathrm{gm} / \mathrm{dL}$ \\
\hline ESR & $48 \mathrm{~mm} \mathrm{in} 1^{\text {st }} \mathrm{hr}$ & $2 \mathrm{~mm} \mathrm{in} 1^{\text {st }} \mathrm{hr}$ \\
\hline Total count & $4100 / \mathrm{cmm}$ & $5400 / \mathrm{cmm}$ \\
\hline $\begin{array}{l}\text { Lymphocytes } \\
\text { differential) }\end{array}$ & $35 \%$ & 27 \\
\hline Platelet count & $158,000 / \mathrm{cmm}$ & $265000 / \mathrm{cmm}$ \\
\hline RBS & $6.7 \mathrm{mmol} / \mathrm{l}$ & $5.7 \mathrm{mmol} / 1$ \\
\hline S. Creatinine & $0.9 \mathrm{mg} / \mathrm{dl}$ & $0.9 \mathrm{mg} / \mathrm{dl}$ \\
\hline SGPT & $67 \mathrm{U} / \mathrm{L}$ & $74 \mathrm{U} / \mathrm{L}$ \\
\hline CRP & $3.1 \mathrm{mg} / \mathrm{L}$ & $4.1 \mathrm{mg} / \mathrm{L}$ \\
\hline S ferritin & $207.1 \mathrm{ng} / \mathrm{ml}$ & $191.40 \mathrm{ng} / \mathrm{ml}$ \\
\hline D-dimer & $0.2 \mathrm{microg} / \mathrm{ml}$ & $0.12 \mathrm{microg} / \mathrm{ml}$ \\
\hline CXR & Normal & Normal \\
\hline S. Electrolytes & Normal & Normal \\
\hline
\end{tabular}

RBS $=$ Random blood sugar; $\mathrm{CXR}=$ Chest $\mathrm{X}$-ray P/A View; $\mathrm{CRP}=\mathrm{C}$-Reactive Protein

When his clinical conditions improved, then he gave throat and nasal swab for follow up after 15 days. As report was negative, he joined to his hospital for providing services on $22^{\text {nd }}$ May. After that, he attended a diagnosed COVID 19 case in indoor on 19th June. He attended the patient with proper personal protective equipment's. After 3 days of the contact, he felt low grade fever and running noses. Then he sent his nasal swab for RT PCR to exclude SARS-CoV-2. He was declared as COVID 19 positive case on $23^{\text {rd }}$ June again.

This time the testing authority performed RT PCR twice and it was positive again (Table 2). The physician was in institutional isolation this time although his fever was low graded. He was started ivermectin $(0.15 \mathrm{mg} / \mathrm{kg})$ for 3 days along with paracetamol and antihistamine. His vital signs and all routine investigation were almost normal also this time (Table 1). On 8 and 10 July, 2020 he gave nasal and throat swab again which came negative on both samples.

Then he was discharged from hospital. Sequencing was not possible to perform. Informed consent was obtained from the physician for publication of this case report. 
Table 2: Result of RT PCR for SARS-CoV-2 of the patient

\begin{tabular}{|l|l|}
\hline $\begin{array}{l}\text { Sample Collection } \\
\text { Date }\end{array}$ & RT PCR Result \\
\hline 3 May,2020 & Positive \\
\hline 18 MAY,2020 & Negative \\
\hline 23 June, 2020 & Positive (done twice) \\
\hline 8 July, 2020 & Negative \\
\hline 10 July, 2020 & Negative \\
\hline
\end{tabular}

\section{Discussion}

Our report describes a physician who was re infected by SARS-CoV-2 after 30 days from initial infection. His initial symptoms were low graded fever and mild cough. He became well without any complications. But after treating a COVID 19 positive case, he felt again low graded fever and running noses. This time also his symptoms were mild.

It is observed that those who retested positive for SARS-CoV-2 RNA after discharge were generally young and had mild COVID-19 disease in the hospital and they did not show any disease progression when readmitted ${ }^{2}$. The spectrum of this disease ranges from mild to severe, even lifethreatening consequences. Host immune response to pathogens may prevent severe illness or reinfection by the same pathogens. Many studies have shown that recovered patients with COVID-19 have antibodies to SARS-CoV-2, some patients have very low levels of neutralizing antibodies. These may be the cause for possible reinfection of SARS-CoV-2 $2^{13}$.

The currently recommended medical observation period for COVID-19 patients is 14 days. According to the WHO's guidelines on clinical management, a patient can be discharged from hospital after two consecutive negative PCR results at least 24 hours apart in a clinically recovered patient ${ }^{14}$. Recently Li et al ${ }^{15}$ reported in the Journal of Medical Virology that prolonged SARS-CoV-2 RNA shedding with a median duration of 53 days and a maximum of 83 days in 36 patients. In another study, a median viral shedding duration of 20 days was observed with a maximum of 37 days ${ }^{16}$. Another studies have demonstrated that cultivatable virus may no longer be recovered from infected hosts 7 days after symptom onset, but more than 28 days viral RNA may be detected by PCR $[17,18]$.

Technical issues in testing may trigger apparent "reinfection" cases, including sample type, sample processing, and test performance. In addition, negative results in samples with low viral loads around the lower limit of detection of the assay are a proposed mechanism for this phenomenon.

It is important to note that the reverse transcription PCR test used to detect SARS-CoV-2 can be very sensitive, and scant RNA fragments can be detected even though the individual is not infectious, shows no symptoms, and has recovered from COVID-19 recently ${ }^{19}$. In the scenario of prolonged PCR positivity, it is important to note that the result of the SARS-CoV-2 RNA test depends on the quality of sample collection (operator dependent) and the viral load of the specimen ${ }^{19}$.

So any of the above causes may happen with our recovered physician. His initial and later both infections were mild in nature. When he was declared negative, there is a certain possibility of RT PCR rendering false negative results, including sampling procedure, sample storage or transport and the sensitivity/specificity of the nucleic acid test kit. It is therefore possible that recurrences should be actually persistent infections in which PCR resulted falsely negative during initial infection when he left home isolation assuming himself disease free. Another cause may be prolonged viral shedding.

This brings up the issue of using more sensitive RNA detection methods before declaring a patient as disease free, and also samples should be taken from two different sites on two consecutive days if needed.

\section{Conclusion}

In case of this case report, it is unclear that the recurrence COVID-19 infection in this physician occurred due to re-infection or he was discharged without full recovery (his follow up sample report may be false-negative during initial infection). It is necessary to avoid false negative and false positive results by performing the coronavirus antibody tests. Considering the significance of this ongoing global public health emergency, it is necessary to carry out large studies to better understand the issue of potential SARS-CoV-2 persistence in COVID-19 patients.

\section{References}

1. Muhammad A. Recurrent covid-19 infection in recovered patients (a critical review). Pakistan Heart Journal. 2020; 53(1)

2. Roy S. COVID-19 Reinfection: Myth or Truth? SN Comprehensive Clinical Medicine. 2020 May 31:1-4.

3. National Guidelines on Clinical Management of Coronavirus Disease 2019 (COVID-19) Version 7.0 28 May 
2020. Available at: https://dghs.gov.bd/images/docs/Guideline /COVID_Guideline_v7.pdf. Accessed on $1^{\text {st }}$ July, 2020.

4. WHO.int. 2020. [online] Available at:
https://doi.org/https://www.who.int/docs/defaultource/coronaviruse/situation-eports/20200420-itrepcovidpdf?sfvrsncf0670b_4 Accessed at 8 July, 2020.

5. Jordan RE, Adab P, Cheng KK. Covid-19: risk factors for severe disease and death. BMJ. 2020;368:m1198. https://doi.org/10.1136/ bmj.m1198.

6. Jwatch.org. NEJM Journal Watch: Summaries of And Commentary On Original Medical And Scientific Articles From Key Medical Journals. 2020. [online] Available at: [Accessed 21 April 2020].

7. Xu Y, Li X, Zhu B, Liang H, Fang C, Gong Y, et al. Characteristics of pediatric SARS-CoV-2 infection and potential evidence for persistent fecal viral shedding. Nat Med. 2020;26(4):502-5.

8. Koyama T, Platt D, Parida L. Variant analysis of COVID19 genomes. [Submitted]. Bull World Health Organ. 2020. https://doi. org/10.2471/BLT.20.253591.

9. Chen D, Xu W, Lei Z, Huang Z, Liu J, Gao Z, et al. Recurrence of positive SARS-CoV-2 RNA in COVID-19: a case report. Int J Infect Dis. 2020; 93:297-9

10. An J, Liao X, Xiao T, Qian S, Yuan J, Ye H, et al. Clinical characteristics of the recovered COVID-19 patients with redetectable positive RNA test. [preprint]. 2020. Available at: https://www.medrxiv.org/ content/10.1101/2020.03.26. 200 44222v1. (Accessed: 08 June 2020).

11. Fu W, Chen Q, Wang T. Letter to the Editor: Three cases of redetectable positive SARS-CoV-2 RNA in recovered COVID19 patients with antibodies. J Med Virol. 2020. https://doi.org/10. 1002/jmv.25968
12. Petruzzi G, De Virgilio A, Pichi B, Mazzola F, Zocchi J, Mercante G, et al. COVID-19: Nasal and oropharyngeal swab. Head Neck. 2020. https://doi.org/10.1002/hed.26212 PMID: 32352180

13. Kang $\mathrm{H}$, Wang $\mathrm{Y}$, Tong $\mathrm{Z}$, Liu $\mathrm{X}$. Retest positive for SARS-CoV-2 RNA of "recovered" patients with COVID-19: Persistence, sampling issues, or re-infection? Journal of Medical Virology. 2020 Jun 3. 7

14. Clinical management of COVID 19. Available at: https://www.who.int/publications/i/item/clinical-managementof-covid-19 Accessed at 7 July, 2020.

15. Li N, Wang X, Lv T. Prolonged SARS-CoV-2 RNA shedding: Not a rare phenomenon. J Med Virol. 2020. doi: 10.1002/jmv.25952.

16. Zhou F, Yu T, Du R, Fan G, Liu Y, Liu Z, et al. Clinical course and risk factors for mortality of adult inpatients with COVID-19 in Wuhan, China: a retrospective cohort study. Lancet 2020. doi: 10.1016/S0140-6736(20)30566-3

17. Wajnberg A, Mansour M, Leven E, Bouvier NM, Patel G, Firpo A, Mendu R, Jhang J, Arinsburg S, Gitman M, Houldsworth J. Humoral immune response and prolonged PCR positivity in a cohort of 1343 SARS-CoV 2 patients in the New York City region. medRxiv. 2020 Jan 1.

18. Wölfel R., Corman V.M., Guggemos W. et al. (2020). Virological assessment of hospitalized patients with COVID2019. Nature. Available at: https://doi.org/10.1038/s41586-020-2196-x. Accessed at $1^{\text {st }}$ July, 2020

19. Can people with previous COVID-19 infection become reinfected by the SARS-CoV-2virus? [updated May 12, 2020]. Available at: https://www.snopes.com/fact-check/covid-19reinfection/ Accessed at $1^{\text {st }}$ July, 2020. 